\title{
符号付有向グラフを用いた化学プロセスの異常診断法
}

\section{-5 段階異常パターンヘの拡張——}

\author{
潮 崎 淳一・松山久義 \\ 田野康 一*.大島栄次** \\ 九州大学工学部 化学機械工学科 ${ }^{\dagger}$
}

\begin{abstract}
正常状態と異常状態を区別するしきい值を，診断すべきプロセスの詳細な定量的情報なしでも決定 できるよらに符号付有向グラフによる異常診断アルゴリズムを改良した。 このアルゴリズムを用いて， マイクロコンピュータによる異常診断システムを作成し，配管系に対する異常診断実験を行った．そ の結果, このアルゴリズムを十分に現実のプロセスに適用できることが示された.
\end{abstract}

\section{緒言}

近年の化学プラントの大型化と複雑化は，異常の自動 的な診断の必要性を増大させている. Iri ら ムを符号付有向グラフで表わし，システムの異常状態を 状態変数の值に対応した 3 段階の符号 (0: 正常, + : 正常值より高い，一：正常值より低い) の組み合わせで 表現し，これを用いた異常診断法を開発した。しかしな がら，この異常診断法を現実のシステムに適用する場合 正常と異常とを区別する限界の值（しきい値）を決定す ることは困難であって，その設定值が不適当な場合には 診断システムは誤診をしたり，診断不能に陥ったりする ことになる。

本論文では，高精度の定量的な情報を用いないでしき い值を決定した場合でる，誤診・診断不能などを避ける ことができる方法として, 測定されている状態変数の值 飞対応する符号として5 段階の符号 $(+,+?, 0,-$ ， 一）を用いた異常診断法を提案する。また，配管系にお ける異常診断実験を行い，3段階の符号を用いた方法と 比較検討し，この診断法の有効性を示す。

\section{3 段階パターンによる異常診断法}

\section{$\mathbf{1} \cdot \mathbf{1} \cdot$ システムの構造と状態の表現}

Iri ら"ばシステムの構造の表現として “符号付有向 グラフ”を, システムの状態の表現として“パターン” を用いることを提案した。

符号付有向グラフは点（状態变数に対応）と有向枝 (状態变数間の因果関係を表現) と有向枝に与兄られた 符号とで構成される. 有向枝の符号は有向枝の始点に対 応する変数が増大（減少）すると終点に対応する変数が

† $\overline{7} 812$ 福岡市東区箱崎 6-10-1

* 旭化成工業(株)

** 東京工業大学 資源化学研究所
増大（減少）する場合（助長）に“+”，始点に対応す る变数が増大 (減少) すると終点に対応する変数が減少 （增大）する場合（抑制）に“一”と定義する.

さらにシステムの状態の表現としては, 状態変数の值 が正常か, 正常值上り高いか, 正常值上り低いかを, そ れぞれ，“0”，“+”，“一”の符号で表わし，すべての状 態変数に対する符号の組合せをパターンと定義する.

このように Iri ら 段階符号”之呼び，その組合せを “ 3 段階パターン” 呼ぶ. “0”でない符号の付いた点を有効点, 始点と終点 の符号の積が枝の符号に等しい枝を有効枝と呼ぶ．また

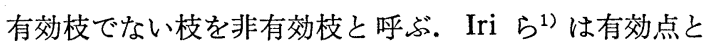
有効枝のみで構成されるグラフを $\mathrm{CE}$ グラフと定義し た. CE グラフはシステム内の異常の伝播状態を表現す るものと考兄られ， $\mathrm{CE}$ グラフの極大強連結成分内の点 は, 異常の原因の候補に対応する.

\section{$1 \cdot 2$ 異常診断アルゴリズム}

実際のシステムに拉いて，すべての状態変数が測定さ れている場合は活とんぞない，符号付有向グラフ内の点 で測定されていない変数に対応する点を非測定点と呼 ぶ.

非測定点が存在する場合には, 非測定点の符号を適当 に仮定して CE グラフを作ればよいはずであるが，この ようにして作られた CE グラフすべてがシステム内の異 常状態を表現しているとは考号れない. Iri ら゙は独 立した 2 つ原因によって異常が発生することは非常に 稀であることから，これらの CE グラフの内，極大強連 結成分が唯一であるもののみ選び，その極大強連結成分 内の点を原因の候補であるとし，それらの点を効率よく 数觉あげるためのアルゴリズムを提案している.

一方 Shiozaki ら ${ }^{2)}$ は有効根付木の概念を提案した。 符号付有向グラフ内のある点から，すべての “0”でな 




(a)
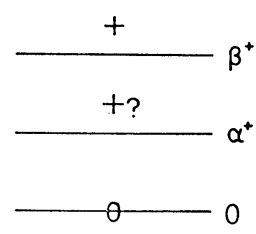

$-?$

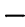

(b)

Fig. 1 3-range thresholds and 5-range thresholds

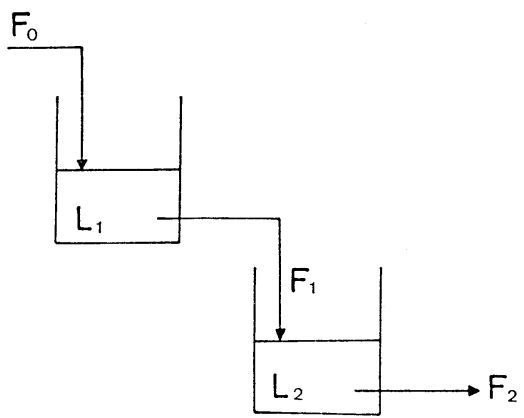

(a)

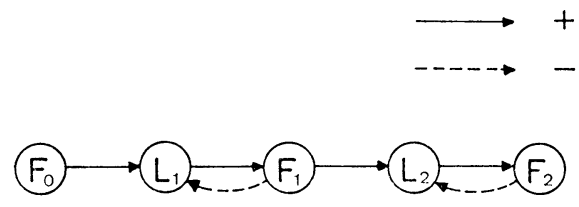

(b)

Fig. 2 Tank system and its signed directed graph

い測定点へ向ら初等的な道が存在し, しかもその道江含 まれる枝がすべて有効枝である場合（有効道と呼ぶ）， その点とそれらの有効道とで構成される木を有効根付木 と呼び，その点をその根と呼ぶ．有効根付木もシステム の異常の伝播状態を表わすものと考光られ，その根は異 常の原因の候補の 1 つである. Shiozaki ら²) は CE グ ラフの極大強連結成分として定義された原因の候補の集 合と，有効根付木の根として定義された原因の候補の集 合とが一致することを証明し，有効根付木の根を効率良 く数えあげるためのアルゴリズムを提案している.

\section{$1 \cdot 33$ 段階パターンの欠点}

現実のシステムに前述の異常診断法を適用する場合に は, 各状態変数に対して, Fig. 1 (a) に示すように, 正 常値の上下にしきい值 $\gamma^{+}, \gamma^{-}$を設定し, 状態变数の值
$F_{0}$
$L_{1}$
$F_{1}$
$L_{2} \quad F_{2}$
$\begin{array}{lllll}\text { (a) }+ & 0 & + & 0 & + \\ \text { (b) } 0 & + & 0 & + & 0\end{array}$
(c) + t? + + +
(d) + ? + t? + t?

Fig. 3 Patterns for the tank system in Fig. 1 obtained by use of improper thresholds

$x$ が, $\gamma^{-} \leq x \leq \gamma^{+}$ならば“0”, $x>\gamma+$ ならば “+”, $x<$ r-ならば “一”と判定して 3 段階バターンを作る。 こ の時に用いるしきい值が不適当である場合には，異常診 断システムは䛊診をしたり，診断不能に陥ったりする恐 れがある。

$\gamma+$ と一-の間隔が広過ぎる場合には，異常を見逃す恐 れがあり，逆に狭過ぎる場合には，正常状態であるにも かかわらず異常診断を行らことになる，また，密接な因 果関係で結ばれているいくつかの変数のしきい值のバラ ンスが悪い場合には誤診をしたり，診断不能になったり する場合も生ずる. 3 段階パターンを作るためのしきい 值の設定には, 各変数間の感度解析等による, かなり高 精度の定量的情報が必要になる。

[例 1] 槽列システムFig. 2 (a) 飞対する符号付有 向グラフは Fig. 2 (b) のようになる.ここで点 $\mathrm{F}_{i}(i=$ $0,1,2)$ は流量, 点 $\mathrm{L}_{i}(i=1,2)$ は液面の高さに対応す る.また, 例总ば $\mathrm{F}_{0}$ から $\mathrm{L}_{1}$ への “+”の有向枝は, $\mathrm{F}_{0}$ が增加（減少）すれば，その直接の影響を受けて $\mathrm{L}_{1}$ も增加（減少）するという “助長” の関係を表わしてい る.

液面の高さと流出流量の間の定量的関係によって, $\mathrm{F}_{0}, \mathrm{~F}_{1}, \mathrm{~F}_{2}$ のしきい值 $\gamma_{F^{+}}, \gamma_{F^{-}}^{-}$と, $\mathrm{L}_{1}, \mathrm{~L}_{2}$ のしきい值 $\gamma_{L}{ }^{+}, \gamma_{L}^{-}$との大きさの間の定量的関係が決をる.

$\gamma_{L}+$ が $\gamma_{F}+$ に比べて大きすぎると， $F_{0}$ の增加によっ て生じた暴常状態において得られるパターンは, Fig. 3 (a) のようになり，独立した 3 つの原因 $F_{0}, F_{1}, F_{2}$ が 存在するかのように䛊診されてしまら.


常状態に打いて得られるパターンは，Fig. 3(b) の上う になり， $\mathrm{L}_{1}$ と $\mathrm{L}_{2}$ とを原因として出力し上うとするが, $\mathrm{L}_{1}, \mathrm{~L}_{2}$ とも原因とはなり得ない変数であるので, 診断不 能に陷る.

符号付有向グラフを用いる異常診断法は, 診断対象と なるシステムに関する定量的な情報が得にくい場合を想 定して開発されたものである。したがって，しきい值の 設定に高精度の定量的な情報を必要とするのでは，本診 断法の有効性が半減することになる。 


\section{5 段階パターンによる異常診断法}

\section{2・1 5 段階パターン}

高精度の定量的な情報を用いないでしきい値を設定し た場合でも，䛊診，診断不能などを避けることができる 方法として, 次汇示す 5 段階パターンを利用した異常診 断法を提案する.

Fig. 1 (b) に示すように, 各状態変数について正常值 の上下にそれぞれ $\alpha^{+}, \beta^{+}$拉よび $\alpha^{-}, \beta^{-}$のつずつの しきい值を設定し, 状態変数の值が $\alpha^{-} \leq x \leq \alpha^{+}$ならば

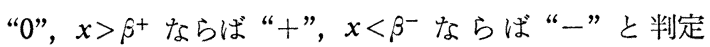
する.ささらに“+?”, “一?”という2つの符号を新たに 導入し， $\alpha^{+}<x \leq \beta^{+}$ならば “+?”, $\beta^{-} \leq x<\alpha^{-}$ならば “一?”之判定する.このようにして生成した符号を 5 段 階符号と呼び, “+?”扣よび “一?”を今後, あいまい な符号と呼ぶ。“十?”は“0”か“十”かは不明である が“一”ではないことを表わし, “一?” は逆に“0”か “一”かは不明であるが “十”ではないことを表わして いる. 5 段階符号の組合せを 5 段階パターンと呼ぶ.

5 段階パターンが与えられた場合に, Shiozaki ら² の3 段階パターンによる異常猃断法を適用すると, 次の ようにして原因の候補の集合 $C$ を求めることができる.

明確な符号 $(+, 0,-)$ を示している測定点（確定 測定点と呼ぶ）の集合を $A$ ，あいまいな符号 $(+?,-?)$ を示している測定点（あいまい測定点と呼ぶ）の集合を $B$ とする. ここでBの中の番目の点の符号を $s_{i}$ として 適正なしきい值を用いた 3 段階符号に沶いて $s_{i}$ のとる 可能性のある符号 $s_{i}{ }^{0}$ と $s_{i}{ }^{1}$ を次のように定義する.



したがって適正なしきい值を用いたとき，B上の 3 段階 パターンとして現われる可能性があるものは，B汇含ま れる点の数を $n$ とすると, 次示す $2^{n}$ 個のパターンで ある。

$$
\left(\begin{array}{c}
\omega_{0}^{B}=\left(s_{1}{ }^{0}, s_{2}{ }^{0}, \cdots, s_{n}{ }^{0}\right) \\
\omega^{B}{ }_{1}=\left(s_{1}{ }^{1}, s_{2}{ }^{0}, \cdots, s_{n}{ }^{0}\right) \\
\cdots \\
\omega^{B_{2}{ }^{n}-1}=\left(s_{1}{ }^{1}, s_{2}{ }^{1}, \cdots, s_{n}{ }^{1}\right)
\end{array}\right.
$$

$A$ 上のパターン (明確な符号のみで構成されている) を $\omega^{A}$ とし, $\omega^{A}$ と $\omega_{i}{ }^{B}$ の和集合 $\omega_{i}$ を確定パターンと 定義する。 $\omega_{i}$ を用いて, Shiozaki ら²)のアルゴリズム により異常診断したときの原因の候補の集合を $C_{i}$ とす れば，すべての測定点上の 5 段階パターンが与えられた 場合の候補の集合 $C$ は次のように表わされる.

$$
C=\bigcup_{i=0}^{2^{n}-1} C_{i}
$$

【例 2] Fig. 2 (a) のシステムに対して 5 段階パタ ーンを用いる場合には, $\mathrm{F}_{0}, \mathrm{~F}_{1}, \mathrm{~F}_{2}$ のしきい值 $\alpha_{\mathrm{F}}{ }^{+}$,
$\alpha_{\mathrm{F}}^{-}, \beta_{\mathrm{F}^{+}}{ }^{+}, \beta_{\mathrm{F}}^{-}$と $\mathrm{L}_{1}, \mathrm{~L}_{2}$ のしきい值 $\alpha_{\mathrm{L}}^{+}, \alpha_{\mathrm{L}}^{-}, \beta_{\mathrm{L}}^{+}, \beta_{\mathrm{L}}^{-}$ との間の定量的関係を䈣密に求める必要はない. $\alpha_{\mathrm{F}}{ }^{+}$, $\alpha_{\mathrm{F}}{ }^{-}, \alpha_{\mathrm{L}}{ }^{+}, \alpha_{\mathrm{L}}{ }^{-}$は, 正常状態に打ける各状態変数の变動 幅から独立に決定することができる. $\beta_{F^{+}}{ }^{+}, \beta_{F}^{-}, \beta_{L}{ }^{+}, \beta_{L}^{-}$ の間には定量的関係があるので，それを感度解析等によ って求めることが望ましいが，正確に求められなくても 不都合は起こらない。

$\mathrm{F}_{0}$ の増加によって生じた異常状態を例にとると, $\beta_{\mathrm{L}}{ }^{+}$ が $\beta_{\mathrm{F}}+$ に比べて大きすぎるときには，Fig. 3 (c) のよう

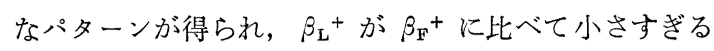
ときには，Fig. 3(d) のようなパターンが得られる.ど ちらの場合にも, 真の原因 $\mathrm{F}_{0}$ を見付けることができ る.

\section{22 アルゴリズム}

Eq. (3) によりCを求めるには $2^{n}$ 回, Shiozaki ら の異常診断アルゴリズムを実行しなければならないが, これでは時間がかかりすぎて実用的でない，効率よくC を求めるアルゴリズムを次に述べる.

5 段階パターンに対する有効道と有効根付木を次のよ うに定義する。

〔定 義〕 初等的な道 $l$ と, それに含まれる測定点 上の 5 段階パターンが与えられたとする.“+?”(“一?”) のあいまい測定点には “+” (“一”), 非測定点には“+” または“一”を適当に与えて，すべての枝が有効枝とな るとき，その道を有効道と呼び，その上に与えられた符 号の組を有効道上のパターンと呼ぶ. 符号付有向グラフ と, その上の測定点上の 5 段階パターンが与えられたと き, ある点からすべての有効な確定測定点へ有効道が存 在するとき，その点とそれらの有効道とで構成される木 を有効根付木と呼ぶ. 有効根付木の根は候補である.

以下では有効な確定測定点の数を $k$, 有効な確定測定 点を $m_{i}(i=1,2, \cdots, k)$ で表わす.

Step 1. $m_{1}$ から枝の向きと逆の方向へ, 次の条件を 満足する点 $a$ を重複を許さない方法で探す.

(1) $a$ から $m_{1}$ へ有效道が存在する.

（2） $a$ は未だ候補として検出されていな い.

もし，そのような点 $a$ が存在しなければ探索終 了. 存在すれば, $a$ を候補と仮定し, 有効道に 含まれるすべての点に番号 1 を付ける． $i=2$ と打く. Step 2 へ.

Step 2. $i>k$ なら有効根付木が完成したので，仮定 していた候補を出力し， Step 1 へ。もしし， $m_{i}$ に番号が付いていれば $i=i+1$ として Step 2 へ. 付いていなければ， $m_{i}$ から枝の向きと逆 の方向へ，始点に番号が付いており終点が $m_{i}$ の有効道を重複を許さない方法で探す。もし， 
(a)



(b)

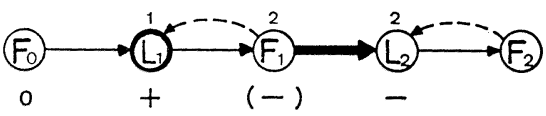

(c)



(d)

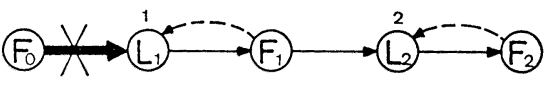

(e)



$(f)$

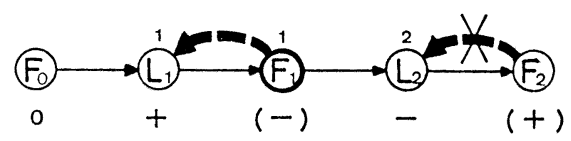

(g)

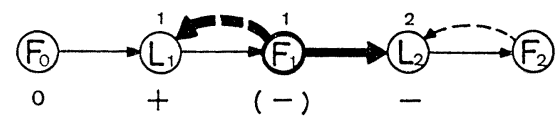

Fig. 4 Application of new algorithm using 5-range pattern to the tank system

その上うな有効道が存在しなければ Step 3 亿。 存在すればその有効道の始点を除くすべての点 に番号 $i$ を付ける. $i=i+1$ として Step 2へ.

Step 3. $i=i-1$ とおく.もし， $i=1$ であれば Step 1 へ. $m_{i}$ に番号が付いていなければ Step 3 へ. 付いていれば番号 $i$ の付いた有効道を変更 し, $i=i+1$ として Step 2 へ. 変更できなけ れば Step 3 へ。

[例 3] Fig. 2(a) の系に括いて, $\left(\mathrm{F}_{0}, \mathrm{~L}_{1}, \mathrm{~L}_{2}, \mathrm{~F}_{2}\right)$ $=(0,+, 一,-?)$ のような 5 段階パターンが得られ, $F_{1}$ は測定されていない場合に対して，上記のアルゴリ ズムを適用すると，次のようになる（Fig. 4 参照）た だし，次の (a) ( g) は，Fig. 4 (a) （g) に対応する.

(a) 有効な確定測定点は $\mathrm{L}_{1}$ と $\mathrm{F}_{2}$ である. $\mathrm{L}_{1}$ 自身 は $\mathrm{L}_{1}$ の上流の点と考えられるので， $\mathrm{L}_{1}$ を候補と 仮定し，番号 1 を付ける． $\mathrm{L}_{2}$ から $\mathrm{F}_{2}$ へさかのぼ ろうとするが， $F_{2}$ の符号は “一?”なので, “+” と仮定できない。

(b)-(c) $\mathrm{L}_{2}$ からさかのぼって, 番号の付いている 点 $\mathrm{L}_{1}$ と結ぶ有効道を見つけようとするが，でき ない。 (d) $\mathrm{L}_{1}$ から $\mathrm{F}_{0}$ へさかのぼって， $\mathrm{F}_{0}$ を候補と仮定 しょうとするが， $F_{0}$ の符号は“0”であり，でき ない。

（e） $\mathrm{L}_{1}$ から $\mathrm{F}_{1}$ へさかのぽって， $\mathrm{F}_{1}$ を候補と仮定 する.

(f) $\mathrm{L}_{2}$ から $\mathrm{F}_{2}$ へさかのぼろうとするが， $\mathrm{F}_{2}$ の符 号は“一?”であったので, “十”とは仮定できな い.

（g） $\mathrm{L}_{2}$ から $\mathrm{F}_{1}$ へさかのぼり， $\mathrm{F}_{1}$ と結ぶ有効道を 見つけることができた．有効根付木が完成したの で， $\mathrm{F}_{1}$ はその根であり，候補である， $\mathrm{L}_{1}$ の上流 における候補の仮定をすべて終えたので，計算を 終了する。

\section{$2 \cdot 3$ アルゴリズムの正当性の証明}

前節のアルゴリズムを用いて診断したときの候補の集 合を $\hat{C}$ とし， $\hat{C}=C$ であることを証明する.

(証明)

ある点 $p$ がCに含まれるための必要十分条件は，与兄 られた 5 段階パターンに対する，ある確定パターン $\omega_{i}$ に対し， $p$ を根とし，次の条件 1 を満足する有効根付木 $T_{p}$ が存在することである.

条件 1 根から確定パターン中の符号が “0”でない すべての点へ有効道が存在する.

ある点 $q$ が $\hat{C}$ に含まれるための必要十分条件は，与 えられた 5 段階パターンに対して，qを根とし，次の条 件 2 を満足する根付木 $\hat{T}_{q}$ が存在することである.

条件 2 根からすべての有効な確定測定点へ有効道が 存在する，ただし，その有効道は “+?” ““?) のあいまい測定点であって, “-”(“+”) と仮 定された点を含まない。

$1^{\circ} C \subset \hat{C}$ の証明

$C$ に含まれる任意の点 $p$ に対応する根付木 $T_{p}$ は，条件 2 を満足する. ( $T_{p}$ の部分グラフで, 根か ら有效な確定測定点へ向から，すべての有効道の和 集合から成る根付木は，条件 2 を満足する.）上っ $\tau, p \in \hat{C}$. すなわち $C \subset \hat{C}$.

$2^{\circ} \hat{C} \subset C$ の証明

$\hat{C}$ に含まれる任意の点 $q$ に対応する根付木 $\hat{T}_{q}$ に 含まれないあいまい測定点に対し，すべて“0”を 割り当て， $\hat{T}_{q}$ に含まれているあいまい测定点に対 しては，すべて $\hat{T}_{q}$ 内で与えられている符号を割り 当てた確定パターン $\omega_{j}$ を考学れば， $\hat{T}_{q}$ は $\omega_{j}$ に対 して条件 1 を満足する根付木である.よって $q \in C$. すなわち, $\hat{C} \subset C$. 


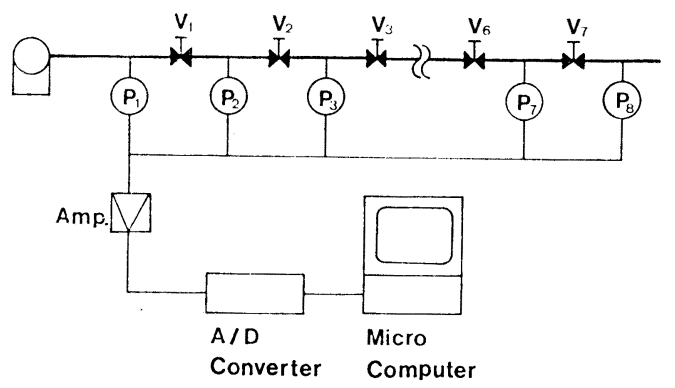

Fig. 5 Experimental apparatus

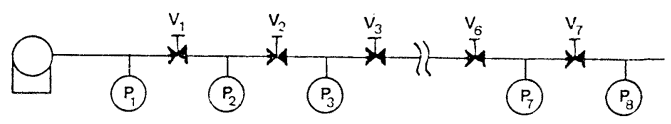

(a)

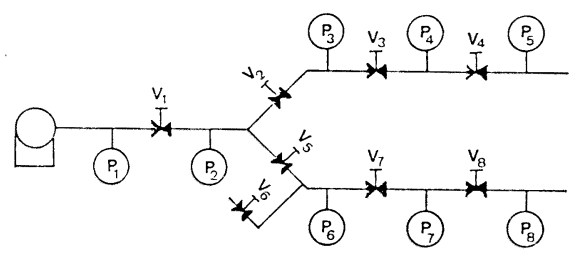

(b)

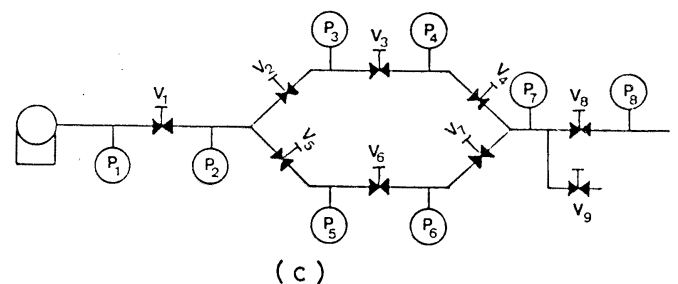

Fig. 6 Pipeline systems

(a) serial system, (b) branching system, (c) by-pass system

\section{3. 配管系における異常診断実験}

\section{$3 \cdot 1$ 実験装置}

装置の概略を Fig. 5 に示す. 配管系の 8 箇所に設置 した圧力計からの信号は, 增幅器, $\mathrm{A} / \mathrm{D}$ 変換器を通し てマイクロコンピュータへ送られ，5段階パターンに変 换されて，異常診断プログラムに入力される. 配管内系 で発生する異常の原因と考えられる“もれ”, “つまり”, “バルブの誤操作” はすべて，実験室内ではバルブの開 閉で表現できるように作られている，異常䜅断の難易は 配管系の構造によって異なるので, 代表的な構造として Fig. 6 亿示す (a) 直列型, (b) 分岐型, (c) バイパス型 の3つを選んで実験を行った．配管内の圧力はすべての


クロコンピュータは Apple II (RAM 48 k Byte) で, プログラムは GAME (General Algorithmic Micro Expression) $)^{3)}$ によって書き, コンパイラにより機械語

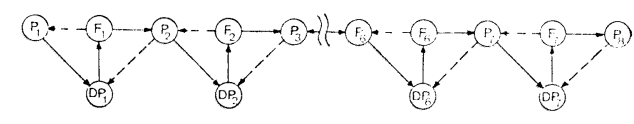

(a)

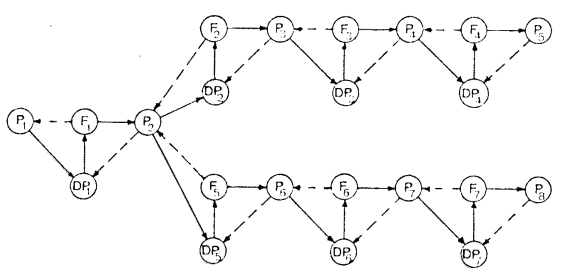

(b)

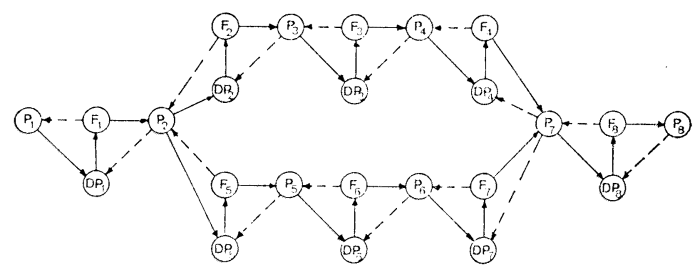

(c)

Fig. 7 Signed directed graphs for the pipeline systems in Fig. 6

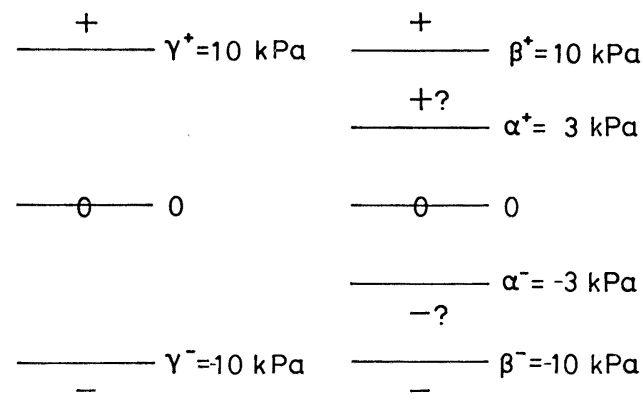

(a)

(b)

Fig. 8 3-range thresholds and 5-range thresholds used in the experiments

に変換したものを用いた．機械語に変換されたプログラ 么の大きさは， $4800 \times 8 \times$ (点の数 $)+4 \times($ 枝の数 $)$ [Byte] で与えられる。

\section{$3 \cdot 2$ 異常診断プログラムの基礎データ}

診断対象として選んだ直列型, 分岐型, バイパス型の 配管系を符号付有向グラフで表現すると, Fig. 7 のよ らになる。実線の矢印は“十”の枝を，破線の矢印は “一”の枝を表わし, $\mathrm{F}_{i}$ は流量, $\mathrm{P}_{i}$ は圧力, $\mathrm{DP}_{i}$ は压 力差に対応する点である. これらの内, $\mathrm{P}_{i}$ は圧力計に よる測定点, $\mathrm{DP}_{i}$ は圧力計からの信号の差による測定点 で, $F_{i}$ のみが非測定点である.

配管系に起こる異常の原因は次に示すようなものであ る. 
Table 1 Patterns and detected candidates for the pipeline systems

\begin{tabular}{|c|c|c|c|c|c|c|c|c|}
\hline Run & \multicolumn{2}{|c|}{1} & \multicolumn{2}{|c|}{2} & \multicolumn{2}{|c|}{3} & \multicolumn{2}{|c|}{4} \\
\hline Pattern & $\mathbf{A}$ & B & $\mathbf{A}$ & B & $\mathbf{A}$ & B & $\mathbf{A}$ & B \\
\hline P1 & 0 & 0 & 0 & 0 & 0 & $-?$ & 0 & $-?$ \\
\hline P2 & + & + & 0 & 0 & - & - & - & - \\
\hline P3 & + & + & 0 & $-?$ & - & - & - & - \\
\hline P4 & + & + & 0 & $-?$ & - & - & - & - \\
\hline P5 & - & - & + & + & 0 & $-?$ & - & - \\
\hline P6 & - & - & 0 & 0 & 0 & - & - & - \\
\hline P7 & - & - & 0 & 0 & - & - & - & - \\
\hline P8 & - & - & 0 & 0 & - & - & - & - \\
\hline DP1 & - & - & 0 & 0 & 0 & $+?$ & + & + \\
\hline DP2 & - & - & 0 & 0 & 0 & $-?$ & 0 & $+?$ \\
\hline DP3 & 0 & $-?$ & 0 & 0 & 0 & $-?$ & 0 & + ? \\
\hline DP4 & + & + & - & - & 0 & $-?$ & + & + \\
\hline DP5 & - & - & + & + & + & + & 0 & $+?$ \\
\hline DP6 & - & - & 0 & $+?$ & - & - & + & + \\
\hline DP7 & - & - & 0 & $\mathbf{0}$ & - & - & + & + \\
\hline DP8 & & & & & & & - & - \\
\hline Candidate & & $-F 4$ & $+\mathrm{F} 4$ & $+\mathrm{F} 4$ & & $-\mathrm{P} 6$ & & $-\mathrm{P7}$ \\
\hline Candidate & & & $-F 5$ & $-F 5$ & & & & \\
\hline No. of Cal. & - & 47 & 10 & 16 & 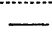 & 88 & - & 274 \\
\hline
\end{tabular}

A: 3-Range Pattern

B: 5-Range Pattern

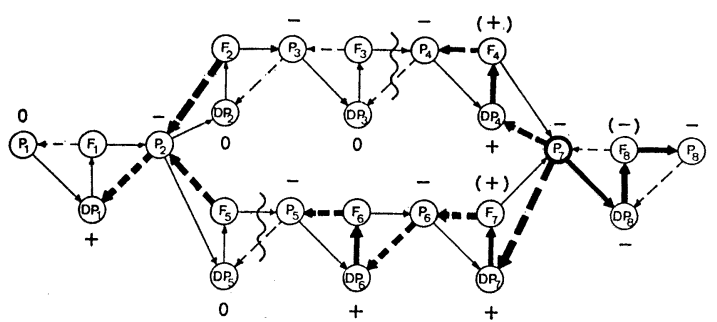

Fig. 9 Incomplete consistent rooted tree corresponding to pattern 4-A in Table 1

配管系の上流に存在する系内の異常：符号付有向グラフ 内では $\mathrm{P}_{1}$ が “+”または“一”となることに対応す る.

配管系の下流に存在する系内の異常：符号付有向グラフ 内では $P_{8}$ （分岐型では $P_{5}$ も）が “十”または“一” になることに対応する。

もれ：符号付有向グラフ内では，圧力 $P_{i}$ が “一”にな ることに対応する.

つまり：符号付有向グラフ内では, 流量 $F_{i}$ が “一”に なることに対応する.

バルブの誤操作：符号付有向グラフ内では流量 $F_{i}$ が “十”(誤って開く)または“一”（說って閉じる）にな ることに対応する.

$\beta^{+}, \beta^{-}$はコンプレッサの起動, 停止による圧力変動 より十分大きく, $+10 \mathrm{kPa},-10 \mathrm{kPa}$ とし, $\alpha^{+}, \alpha^{-}$は 電気回路の雑音による測定值の変動の程度に合わせて, $+3 \mathrm{kPa},-3 \mathrm{kPa}$ とした (Fig. $8(\mathrm{~b})) . \gamma^{+}, \gamma^{-}$は $\beta^{+}$, 邽と同じとした (Fig. $8(\mathrm{a})$ ).



Fig. 10 Consistent rooted tree corresponding to pattern 4-B in Table 1



(a)

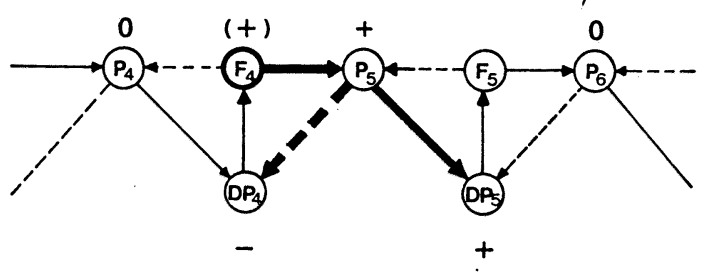

(b)

Fig. 11 Consistent rooted trees corresponding to pattern 2-A in Table 1

\section{$3 \cdot 3$ 実験結果}

種々の条件で実験を行ったが，その内，代表的なもの として, 次の 4 つの実験について報告する.

Run 1: 直列型における管のつまり

バルブ $\mathrm{V}_{4}$ (上流から4 番目のバルブ) を絞 って管のつまりを表現した．符号付有向グラフ 上の点 $\mathrm{F}_{4}$ が “一”になったことに対応する.

Run 2: 直列型に拉けるバルブの誤操作

バルブ $\mathrm{V}_{4}$ を䛊って開いたとして表現した. 点 $\mathrm{F}_{4}$ が “+”になったことに対応する.

Run 3: 分岐点に括けるるれ

バルブ $\mathrm{V}_{8}$ (Fig. 6(b) 参照) を開くことです れを表現した。点 $\mathrm{P}_{\theta}$ が“一”になったことに 対応する。

Run 4：バイパス型におけるもれ

バルブ Vo (Fig. 6(c) 参照) を開くことで表 現した. 点 $\mathrm{P}_{7}$ が “ー”になったことに対応す る.

以上 4 つの実験の結果を Table 1 にまとめて示す. 3 段階パターンを用いた場合には，Run 2 に対しての 
み診断可能で, 他は診断不能（有効根付木を作ることが できない）となる。その理由は，例えば Run 4 におい て 3 段階パターンを用いると $\mathrm{DP}_{2}, \mathrm{DP}_{3}, \mathrm{DP}_{5}$ が“0” となるため, Fig. 9 に示すよらにグラフば切断されて しまい，有効根付木を作ることができなくなるからであ る.一方，5段階パターンを用いれば， $\mathrm{DP}_{2}, \mathrm{DP}_{3}, \mathrm{DP}_{5}$ が“十?”となるため，Fig. 10 に示すような有効根付 木を作ることが可能になる. Run 1 および Run 3 に ついても同様である.

Run 2 では 3 段階パターンと 5 段階パターンの両方 の場合において，2つの候補を検出しているが，これは 与觉られたパターンから 2 種類の有効根付木 (Fig. 11) を作成することができるためである，また， 3 段階パタ ーンを用いても誩断可能な場合は, 演算回数（枝を 1 本 たどる演算を単位として）は，3段階パターンを用いた 方が幾分速くなったが，理論的には，逆になる可能性も 存在する.

\section{結言}

従来の 3 段階パターンによる異常診断法を改良し，し きい值の設定不良による䛊診や診断不能をさける方法と して 5 段階パターンによる異常診断法を開発した. マイ クロコンピュータを用いて異常診断システムを作成し, 配管系の異常診断実験を行って，この方法を用いれば高 精度の定量的な情報を利用しないでしきい值を設定した 場合でも, 誤診や診断不能に陷ることがなく, かつ, 演 算回数の増加は極くわずかであることを示した.

\section{Nomenclature}

$A=$ set of explicitly measured nodes

$B=$ set of ambiguously measured nodes

$C, \hat{C}=$ set of candidates

$C_{i}=$ set of candidates fro $\omega_{i}$

$D P_{i}=i$-th pressure difference

$F_{i}=i$-th mass flow rate

$k=$ number of valid explicitly measured nodes

$L_{i} \quad=$ level of $i$-th tank

$P_{i}=i$-th pressure

$n \quad=$ number of ambiguously measured nodes

$s_{i}=5$-range sign of $i$-th ambiguously measured nodes

$s_{i}{ }^{0}, s_{i}{ }^{1}=3$-range signs corresponding to $s_{i}$

$T_{p}=$ consistent rooted tree whose root is $p \in C$

$\hat{T}_{q}=$ consistent rooted tree whose root is $q \in \hat{C}$

$x \quad=$ state variable

$\alpha^{+}, \alpha^{-}, \beta^{+}, \beta^{-}=$thresholds for 5-range pattern

$\gamma^{+}, \gamma^{-}=$thresholds for 3-range pattern

$\omega_{i}=i$-th explicit pattern

$\omega^{A} \quad=$ pattern on $A$

$\omega_{i}^{B}=i$-th 3-range pattern on $B$

\section{Literature cited}

1) Iri, M., K. Aoki, E. O'shima and H. Matsuyama: $J$. Operations Research Soc. Japan, 23, 295 (1980)

2) Shiozaki, J., Y. Tsuge, H. Matsuyama and E. O'shima: To be published

3) Suzuki, N.: $A S C I I$, No. 32, 68 (1980)

(1983 年 6 月 4 日受理; 化学工学協会第 46 年会 (名古屋, 1981 年 4 月) にて発表)

\title{
Diagnosis of Chemical Processes by Use of Signed Directed Graphs
}

- Extension to 5-Range Patterns of Abnormality-

\author{
Junichi Shiozaki, Hisayoshi Matsuyama, Kouichi Tano* \\ and Eiji O'shima**
}

Dept. of Chem. Eng., Kyushu Univ., Fukuoka 812

\begin{abstract}
Key Words: System Engineering, Safery, Fault Diagnosis, Graph Theory, Signed Directed Graph
\end{abstract}

The algorithm for fault diagnosis by use of the signed directed graph was improved, where the thresholds distinguishing normal and abnormal states based on qualitative information about the process are to be applied. The algorithm was implemented on a microcomputer to be tested for fault diagnosis of a pipeline system as an experimental example. It was proved through experiment that the present algorithm possesses potential applicability to practical process systems.

* Asahi Chemical Industry Co., Ltd.

** Research Lab. of Resources Utilization, Tokyo Inst. of Tech. 